\title{
Analysis of Accounting Reforms in the Public Sector of Pakistan and Adoption of Cash Basis IPSAS
}

\author{
Miraj Javed", Wang Zhuquan \\ College of Management, Ocean University of China, Qingdao, P. R. China
}

Copyright $\mathrm{O} 2018$ by authors, all rights reserved. Authors agree that this article remains permanently open access under the terms of the Creative Commons Attribution License 4.0 International License

\begin{abstract}
Streamlining the accounting system in accordance with "world's best practices" will result in consistency and transparency in the financial management of the country, ensure good governance, boost the confidence of investors, and contribute to strengthening the economy. The public sector accounting system in Pakistan has been overhauled recently. The reforms have been implemented by the Federal Government of Pakistan (GOP), with the assistance of World Bank, through Project to Improve Financial Reporting and Auditing (PIFRA). This study describes the accounting reforms implemented by the GOP and the adoption of cash basis International Public Sector Accounting Standards (IPSAS) for financial reporting. We first describe the contents of the accounting reforms implemented in all levels of the country beginning in the 1990s and briefly introduce cash basis IPSAS. Second, we assess the compliance of Pakistan's accounting system with cash basis IPSAS and IPSAS-2 cash flow statement. Finally, we conclude that the financial statements of the GOP comply with the requirements of cash basis IPSAS. This study recommends transitioning from cash to accrual accounting system because Pakistan has reflected a satisfactory margin after the new reforms have been implemented.
\end{abstract}

Keywords Public Accounting, IPSAS, PIFRA, New Accounting Model, GOP

\section{Introduction}

Public sector accounting has become an important global topic in recent years. The effect of public sector accounting on public financial management and accountability has significantly influenced the socio economic development of the country. An effective accounting system allows the government to manage its finances smoothly and provides audit trails to avert and detect financial misconduct [15]. After facing deficits, high-level debts, and budgetary instability, many governments began to appreciate the significance of high-quality financial reporting; financial crises increase the demand for effective financial management in public sector accounting for transparency and financial reporting [8]. Public sector accounting is a key factor to the growth of a nation, and recent advances in the field of accounting show that public sector accounting and financial reporting reforms are useful if adopted in all government levels [9]. Chartered Institute of Public Finance and Accounting defines financial management as "the system by which financial management resources are planned, directed, and controlled to enable and influence the efficient and effective delivery of public service goals" [10]. Numerous countries have begun to realize the importance of good financial management in public sector entities, especially after the emerging of international accounting standards, many countries and some intergovernmental organizations adopted IPSAS because it considers the best practices and alternative reforms for government entities in evaluating financial reports. The harmonization of public sector accounting generates outcomes similar to those of the business sector, although public sector accounting is considered less important than private sector accounting in the international market [16]. Developed and developing countries should pay considerable attention to the global clamor for efficient public financial management that ensures accountability and transparency. [2]. World Bank (WB), International Monetary Fund (IMF), and Asian Developed Bank (ADB) are the main sponsors of financial reforms in less developed countries (LDCs). Since 1980, they have initiated programs for budgeting and accounting reforms in the public sector of LDCs, which are also the key features of New Public Management (NPM), proposed for LDCs to improve transparency and accountability in resource allocation and service delivery [6]. Changes in global trend and the involvement of international institutions motivate the GOP to implement a paradigm shift in public sector financial management accordance with the best international practices. The GOP has modified its legislation to implement the reforms under Ordinance 2001. 


\section{Background and Objective of Study}

This study describes the accounting reforms adopted in public sector implementation and compares the financial reports of the GOP with cash basis IPSAS and IPSAS-2. In Pakistan, minimal work has been carried out on public sector accounting. Most studies focus on the private sector despite the importance of public sector accounting and its need for further research. This study provides sound knowledge of public sector accounting reforms in Pakistan. Analyzing the current accounting system with International System I will help in further research and enable stakeholders to visualize clearly the current accounting system of Pakistan.

\section{Methodology}

This is a descriptive research that uses the case study approach to describe the public sector accounting reforms and the compliance of the GOP annual financial reports with cash basis IPSAS and IPSAS- 2 cash flow statement. This study utilizes secondary data; Documents analyzed in this study include the WB report for 2007, IPSAS, new accounting model (NAM) manuals, and financial statements of the GOP from 2009 to 2016. In addition, reviewed media reports on government accounting standards, Auditor-General (AG) and Controller General Reports and related newsletters are considered.

\section{Literature Review}

\section{Public Sector Accounting Reforms in Pakistan}

Since independence, Pakistan has been implementing the British accounting system, which is based on Accounting Code I-IV. This accounting system is dual in nature. The British army, deployed in the subcontinent, maintains separate accounts and uses a different format for the civil sector [3], while public sector accounting follows the non-commercial system. Global harmonization in public sector accounting prompts the government to introduce reforms in the government accounting practice in Pakistan [3].The PIFRA reforms were begun in the 1990s [4]. Currently, the NAM is implemented using the SAP/R3 application for government accounting [3]. The current accounting reforms in the government sector of Pakistan were initiated in 1997 through PIFRA and financed by WB under the supervision of the AG of Pakistan. The major change in the accounting system involves separating the office of the AG from the Controller General of Accounts (CGA) through ordinance 2001 [3]. The IMF conducted a survey for reforms through a diagnostic study sponsored by WB and project partner ADB [5]. The accounting and auditing system of all government entities of Pakistan were obsolete and required harmonization. Inadequate system for financial data, and lack of skilled staff resulted in unsatisfactory planning, budgeting and reporting, and ineffective internal controls. Cash, asset, and debt positions were unreliable. Some commitments/obligations were unidentified. Pensions and depreciation records were not maintained. These contributing factors caused uneven resource allocation and led to weak governance and accountability [5]. Project to Improve Financial Reporting and Auditing mainly aimed to guarantee transparency in government and donor development funds, enhance the accountability of government revenue and expenditure, reinforce the decision-making and budgeting processes, as well as offer realistic information to the public [5].

\section{IPSAS}

IPSAS supports transparency and accountability in public sector organizations and improves the quality of financial information reporting [10]. The main purpose of IPSAS is to improve the quality of the general purpose financial reports (GPFRs) of public sector entities for decision-making and allocation of resources. Compliance with IPSAS standards ensure that the financial reporting of public entities reflects a true and fair view of the financial position and shows transparency and accountability in the management of public resources. It brought excellence in financial management and thereby increasing the confidence of investors and gaining public trust. IPSAS enables the comparison of financial reports with those of other countries and motivate raising capital from international markets [7]. Sovereign debt crisis, which has affected many countries, including the European Union and the United States, is caused by the lack of government transparency and accountability, poor financial management, poor public sector financial reporting, and the lack of institutions for fiscal management; these weaknesses constrain the government from managing financial resources to protect the interests of the public and other investors [10]. The establishment of the World Trade Organization and the partnership agreement between countries force developing countries to implement reforms in their economic and development policies and move to NPM to integrate with the world economy [9]. The healthier financial management ensured greater accountability and transparency, alleviated the apprehension of both developed and under developed countries, and reduced anxiety by using IPSAS in preparing the GPFRs designed and promoted by the International Federation of Accountants [7]. The basic aim of IPSAS is to improve the quality of public sector GPFR, ensure government transparency and accountability, and promote the assessment of resource allocation decisions and conformity with global best practices and sustainability reporting. Financial stewardship is promoted and all stakeholders have great confidence in public sector organizations; effective financial management plays an important role in decision-making and resource allocation 
[10]. The central government, a key regulator, is exclusively responsible for determining the standards for businesses and the public sector through legislation [8]. Public sector is the part of the national economy where economic and non-economic activities are controlled and directed by the government [11]. The high implementation cost of IPSAS discourages public sector entities from adopting its standards. IPSAS cost includes training, hiring, consultancy, organizational changes, IT investments, and other overheads, depending on the activity and nature of the entity. A project team and managerial support are required to accomplish the project. Harmonization in Public sector financial management is ongoing process, which gradually leads to amendments of existing IPSAS and the issuance of new IPSAS [12].

\section{Harmonization of Public Sector Accounting in Pakistan}

The public sector accounting practice in Pakistan dates back to its independence. The manual system became obsolete because of its perpetual method of recording transactions and inept reporting system, which affected the decision-making process of the government. The inadequate financial reporting system affected the economic development of the country and caused distrust in welfare services. Reforms in public sector accounting and adoption of international accounting standards were greatly needed. The overhaul of public accounts in Pakistan began in 1997, the WB has supported the comprehensive reform efforts of the GOP to modernize its accounting and auditing system and procedure while improving the institutional and individual potential for efficient public financial management [2]. To bring about transparency and accountability and improve the quality of public sector GPFR as per international standards, Accountant General of Pakistan prescribed NAM and cash basis IPSAS. The Constitution of Pakistan introduces the legislative framework for financial management in federal and provincial governments. Articles 78 to 88 and 118 to 127 cover the financial procedure for federation and provinces, respectively, Articles 169 to 171 include the functions and powers of the AG. The Pakistan (Audit and Accounts) Order 1973 states that the AG will be responsible for keeping the accounts of the federation and each province. The Order was issued subsequent to Article 170 of the Constitution, which indicates that "the accounts of the Federation and of the Provinces shall be kept in such form and in accordance with such principles and methods as the Auditor-General may, with the approval of the President prescribe" [1].

In 1996, the GOP, with support from the World Bank, initiated PIFRA to institute financial reforms in public sector accounting and auditing. The main objective of the project was to adopt and implement international accounting and auditing standards for the improvement and modernization of the public accounting practice and financial reporting. Before the PIFRA, the budgetary accounting system used by the GOP was manual and unable to produce comprehensive reports for public financial management. The budgetary and accounting data for financial reporting were insufficient.

The PIFRA, which was implemented in three phases between 1996-2014 at all federal, provincial, and district levels of the government, introduced the NAM with the use of Enterprise Resource Planning (ERP) SAP/R3 and a new chart of accounts [5]. The NAM is a set of seven manuals comprised of accounting policies and principle, procedures, and reporting standards of the GOP. The NAM is designed for the major financial activities of accounting entities whose principal funding is appropriated from the GOP. The basic purpose of the NAM is to improve the traditional accounting system and interpret the budgetary activities of the government by introducing a shift toward modified cash basis accounting, double-entry bookkeeping, commitment accounting, fixed asset accounting, and a multi-dimensional chart of accounts. The NAM has all the basic features, such as structure of the model with its individual accounts, the principles of budgeting and accounting, the preparation of annual financial statements, budget management, and financial reporting [17]. The SAFA (2006) claimed that the NAM can be converted into accrual-based accounting system with some modifications [18]. The NAM is supported by the SAP-ERP based system and is adopted in more than 500 cities across the country at federal, provincial, and district levels. The district accounts offices (DAOs), other district level offices, and provincial line departments are linked through a wide area network (WAN) to servers at the AG Office and the Finance Department of their respective provinces. All provincial servers are linked through WAN to the federal server at the office of the AG of Pakistan Revenues (AGPR) in Islamabad, thereby creating a seamlessly integrated system capable of providing real-time information on financial transactions taking place across the country at national and sub-national levels (PIFRA). The FABS is used to process the following: (a) monthly salary of more than 2.5 million government employees at the federal, provincial, and district levels; (b) monthly pension of more than 0.5 million government employees; (c) General Provident Fund payments of government employees; (d) thousands of payment claims of government departments across the country on a daily basis; (e) monthly and annual accounts of federal, provincial, and district governments; and (f) budgets of federal and provincial governments.

The second phase of the PIFRA project, PIFRA-II, was introduced at the district and sub district levels, which strengthens the financial accountability cycle. The aim of the GOP to improve public financial management, accountability, and transparency is supported by the project, and the ability of public sector managers to utilize credible financial information for effective and informed decision making is enhanced. The use of public monies will be effectively monitored, and the national as well as 
international credibility of the financial statements and assurance processes of national as well as provincial governments will be improved [2].

\section{Adoption of Cash Basis IPSAS:}

Cash basis IPSAS issued to encourage those entities who only record and maintain cash transactions, this standard enhance the accountability in cash receipt, cash payment and cash balance of those entities which compliance their GPFR, s with this standard. Cash basis IPSAS consists of two parts: mandatory and non-mandatory. The financial reports of every entity must comply with the mandatory standards and be prepared per cash basis IPSAS. These include the requirements of presentation of financial statements on cash basis, disclosure of accounting policies with supporting notes, and presentation of budget information. The non-mandatory requirements of cash basis IPSAS identify additional accounting policies and guidelines for public entities interested in migrating to accrual basis accounting in the future (Handbook reference). The basic objectives of the adoption of this standard are as follows:

- Support the cash basis accounting system of public entities that maintain only the records of cash receipt and payment. This standard prescribes a manner of presentation of financial statements/annual reports.

- Comply with the requirements and enhance the accountability and transparency of cash payments and receipts, support decision making and legislation, and analyze financial performance in comparison with previous record or other entities.

- Encourage public entities to migrate to accrual basis accounting. This part involves the additional disclosure of non-cash items and cash flow statement.

\section{Compliance with Cash Basis IPSAS:}

Financial statements comply with IPSAS only if they fulfill all the requirements of each applicable standard. The compliance of the financial reports of the GOP with international standards is verified through the following analyses.

\section{Cash Basis}

Cash basis IPSAS apply to entities that prepare and present financial statements using the cash basis of accounting, that it, the recognition of transaction when the cash is received and paid. The accounting policy and procedure manual of the NAM explains the accounting basis of the GOP, which is involves double entry accounting, modified cash basis, commitment accounting, and assets and liability management. Notes to the financial statement disclose that the financial reports of the GOP have been prepared in accordance with cash basis accounting.

\section{Accounting Policies}

Accounting policies are rules and procedures applied by an entity to prepare its financial statements. The accounting policies are not disclosed in detail on the face of the financial statements but on the manual of accounting policy and procedure used for the financial transitions of the GOP, which is publicly available on the website. This manual shows the detailed financial setup of the GOP.

\section{Financial Statement}

Cash basis IPSAS standardizes the financial statements comprised of the following:

- Cash receipt and payment statement

- Identification of third party payment

- Accounting policies and explanatory note

- Statement of the comparison of budget and actual amounts

Article 10 of the Pakistan Audit and Accounts Order 1973 requires the AG to prepare the financial statements of the federal government and all provinces. The financial statements of the Federal GOP have been prepared per the requirements of the NAM. The financial reporting manual details the compliance of the government financial reporting process with cash basis IPSAS requirements. The financial statements of the Federal GOP satisfy all the requirements of IPSAS. Cash receipts, payments, and balances are reported on gross basis. Payments made by third parties on behalf of an entity are disclosed separately on the statement of cash receipt and payment and comparative budget statement.

\section{Reporting Entity:}

This part of cash basis IPSAS requires disclosure of reporting entity, which enable users to identify its nature and the legislative and institutional environments where it operates. The accounting entities in the GOP include centralized accounting entities, self-accounting entities, and exempt entities at federal and provincial government levels. The federal government and government of four provinces (Sindh, Baluchistan, Punjab, and KPK) are separate accounting and reporting entities. The financial statements of the GOP cover all centralized and self-accounting entities, except the Pakistan Railway.

\section{Notes to the Financial Statements:}

This part of financial statement provide information about the basis of preparation of financial statement, it contain all the necessary information which is no presented on the face of financial statement, such as accounting policies and other events selected and applied for significance transaction, shows the fair presentation of cash receipts, cash payments, and cash balance. Information relating to preparation and accounting policies are incorporated in the financial reports of the Federal GOP. 


\section{General Considerations:}

The following general considerations are the mandatory requirements of cash basis IPSAS for presentation of financial statements:

- Reporting date

- Timeline

- Authorization date

- Comparative information

- Identification of financial statements

- External assistance

- Consistency

- Authorization Date

The budgetary and accounting period in Pakistan is fixed and runs from July 01 to June 30 of the following year. Per financial reporting manual, the financial statements must be issued before October 30 each year (within three months of the reporting cycle) and prepared by the CG. The AG of Pakistan is responsible for issuing a financial report to all stakeholders before October 30. The preparation of financial accounts in the government accounting system is consistent, and comparative information is disclosed for all numeric information. The financial reports of the Federal GOP satisfy the requirement of clearly identifying all financial statement information and distinguishing them from other information in the same published document. The external assistance received by the GOP during the period is disclosed in the receipt and payment statement in the head of development grants and the provider of external assistance is identified in the notes portion. However, the other details of external assistance as required by the standard are not disclosed on the financial reports.

\section{Non-Mandatory Requirements of Cash Basis IPSAS:}

This part of cash basis IPSAS identifies additional accounting policies and disclosure that encourages the entity to enhance financial accountability and transparency and add more detail. The financial statements of the GOP have been prepared under cash basis of accounting. The statement of assets and liability has been presented, which is not mandatory but encourages disclosure per international standards. Going concern assessment shows the ability of the entity to continue as a going concern. Pakistan is a sovereign state to which generally accepted accounting principles (GAAP) are applied to prepare financial statements, thereby satisfying the requirement. The financial reports of the Federal GOP do not provide any disclosure about extraordinary items, agency transactions, disclosure in notes to accounts, hyperinflationary economy, assistance from external agencies and NGOs, and treatment of flows from acquisition/disposal. Some of the above requirements, such as hyperinflationary economy, are not applied in Pakistan.

\section{IPSAS 2- Cash Flow Statement}

Cash flow statement shows the chronological changes in cash and cash equivalents of an entity during the period, classifies the inflow and outflow of cash during the period from operating, investing, and financing activities and assists entities in predicting cash position and the ability to generate cash in the future. IPSAS-2 cash flow statement was issued in May 2000, and 24 amendments were made from year 2000 to January of 2015.

The GOP adopted IPSAS -2 formats of cash flow statements in the financial statements of 2008-2009, reports the cash flow in three separate disclosures: cash from operating, investing, and financing activities. Regarding the compliance with IPSAS 2 cash flow statement, the format has been adopted but the disclosures required by IPSAS- 2 cash flow statement are not included, such as reconciliation of net cash flow from operating activities. IPSAS encourage disclosure of reconciliation of surplus or deficit to operating cash flow in the notes to the financial statements. No breakdown for the receipt of non-tax revenue and other receipts, operational payments, transfers and expenditure on physical assets, civil work and others are disclosed in the notes of the financial statements.

\section{Discussion}

This study discusses the public sector accounting system reforms in Pakistan and adoption of cash basis IPSAS for financial reporting. The PIFRA reforms became effective components of financial management in Pakistan's public sector. PIFRA was implemented over a period of more than five years to build the channel of communication at the local, regional, and national levels. The PIFRA is equipped with all the elements necessary for good financial management. This study shows that the financial reports of GOP broadly comply with cash basis IPSAS and IPSAS-2 cash flow management. The current accounting reforms in Pakistan provide evidence of the modernized accounting system in public sector of Pakistan and its flexibility in absorbing the changes and do modification per international standards. The NAM with a new chart of accounts supports the dual accounting system. The GOP currently maintains accounts and financial reports using the modified cash basis system. The PIFRA reforms can record the transactions and maintain accounts on full accrual basis and lean toward modified accrual than modified cash basis. Accrual basis accounting systems enhance accountability and transparency in government sector and monitor debts and liabilities. The current cash basis of accounting system does not provide appropriate incentives for decision makers because only cash transactions are reported. Non-cash transactions are ignored although they contribute to the economy and give direction to government to act now and into the future to address long-term sustainability and ensure the welfare of future generations. A great disadvantage of cash basis accounting is that it does not recognize assets, debtors, and liabilities. The hidden debts of government are not reported 
and a realistic view of government financial position is not presented. The PIFRA reforms are the most encouraging incentives to move to accrual accounting. Transactions are recorded in real time using the new chart of accounts per dual concept of GAAP in SAP ERP system and reports can be generated at any stage in the process.

Under cash basis accounting, the financial results for the period is measured as the difference between cash received and cash disbursed. The sources and uses of cash are provided. Per the PIFRA reforms, the financial activities of the GOP are not limited to cash accounting and the detailed chart of accounts contains separate codes for all financial statement elements (assets, liabilities, expenses, revenue, and equity).

\section{Conclusion and Recommendation}

This paper focuses on current accounting reforms in Pakistan's public sector that are implemented through the PIPRA and the compliance of the Federal GOP's financial reports with cash basis IPSAS. This study can be extended in the future. This study concludes that the PIFRA reforms are geared toward transformation to full accrual accounting system. The implementation of the NAM with SAP was well-received in the GOP accounting system. The PIFRA reforms satisfy all the requirements to transition to an accrual accounting system and develop an integrated accounting system for all levels of the GOP. For better financial management and fair financial position, we recommend following the accrual basis of accounting and adopting IPSAS. Moreover, we encourage further research in the field of public sector accounting.

\section{LIST OF ABBREVIATIONS AND ACRONYMS}

\begin{tabular}{|c|c|}
\hline $\mathrm{ADB}$ & Asian Developed Bank \\
\hline $\mathrm{AG}$ & Auditor-General \\
\hline AGPR & Accountant General Pakistan Revenue \\
\hline CGA & Controller General of Accounts \\
\hline DAOs & District accounts offices \\
\hline ERP & Enterprise Resource Planning \\
\hline FABS & Financial Accounting and Budgeting System \\
\hline GAAP & Generally accepted accounting principles \\
\hline GOP & Government of Pakistan \\
\hline GPFRs & General purpose financial reports \\
\hline $\mathrm{IMF}$ & International Monetary Fund \\
\hline IPSAS & International Public Sector Accounting Standards \\
\hline KPK & Khyber Pakhtunkhwa \\
\hline LDC's & less developed countries \\
\hline NAM & new accounting model \\
\hline NGOs & Non-government organizations \\
\hline NPM & New Public Management \\
\hline PIFRA & Financial Reporting and Auditing \\
\hline SAFA & South Asian Federation of Accountants \\
\hline SAP & System Applications and Products \\
\hline WAN & wide area network \\
\hline WB & World Bank \\
\hline
\end{tabular}

\section{REFERENCES}

[1] N. Assembly, "The Constitution of the Islamic Republic of Pakistan," 2012.

[2] I. Standards, "Pakistan Public Sector Accounting and Auditing: A Comparison to International Standards," no. May, 2007.

[3] A. Economic and F. Review, "Accounting from a Religious Perspective: A Case of the Central Government Accounting in Islamic Republic of Imtiaz Badshah Frode Mellemvik Konstantin Timoshenko," vol. 3, no. 2, pp. 243-258, 2013.

[4] Y. A. Zia and M. Z. Khan, "Drivers of Public Sector Reforms in Pakistan: A Comparison of NPM with Alternative Reform Drivers."

[5] "Improving public sector financial management in developing countries and emerging economies."

[6] "No Title," pp. 1-23.

[7] M. Samuel and T. Ph, "Factors Influencing the Acceptance of International Public Sector Accounting Standards in Cameroon," vol. 5, no. 2, pp. 71-83, 2016.

[8] I. Brusca, V. Montesinos, and D. S. L. Chow, "Legitimating International Public Sector Accounting Standards (IPSAS): the case of Spain," no. November 2014, pp. 37-41, 2013.

[9] N. Nagendrakumar, "The Development of Public Sector Accounting and Financial Reporting in Sri Lanka," vol. XV, no. 2, pp. 70-88, 2015.

[10] M. Ifeoma, K. Nonyelum, A. John, P. Awheela, and U. Ali, "Sustainable National Economic Development in Nigeria: The Relevance of International Public Sector Accounting Standards (IPSASS),” vol. 3, pp. 88-98.

[11] "A Critique on Cash Basis of Accounting and Budget," vol. 2, no. 3, pp. 69-83, 2014.

[12] M. Kr, "Disclosure of Financial Information about the General Government Sector by IPSAS," pp. 485-495, 2017.

[13] S. Bellanca and J. Vandernoot, "Analysis of Belgian Public Accounting and Its Compliance with International Public Sector Accounting Standards (IPSAS) 1, 6, and 22," vol. 8, no. 9, pp. 122-133, 2013.

[14] IFAC International Federation of Accountants and IFAC, International Public Sector Accounting Standards Board Handbook of International Public Sector Accounting Pronouncements 2012 Edition, vol. II. 2015.

[15] James L. Chan "IPSAS and Government Accounting Reforms in Developing Countries:

[16] Bernardino Benito, Isabel Brusca and Vicente Montesinos "The harmonization of government financial information systems:-the role of the IPSASs: International Review of Administrative Sciences Vol. 73(2):293-317.

[17] THE NEW ACCOUNTING MODEL OF THE SWISS CONFEDERATION "OECD JOURNAL 4 ON 
BUDGETING - VOLUME 8 - No. 1 - ISSN 1608-7143.

[18] South Asian Federation of Accountants (SAFA). (2006). A study on accrual-based accounting for governments and public sector entities in SAARC countries, September. 